\title{
Recurrence rate in regional lymph nodes in 737 patients with follicular or Hürthle cell neoplasms
}

\author{
Andrej Vogrin', Hana Besic ${ }^{2}$, Nikola Besic², Maja Marolt Music ${ }^{1}$ \\ 1 Department of Radiology, Institute of Oncology Ljubljana, Ljubljana, Slovenia \\ 2 Department of Surgical Oncology, Institute of Oncology Ljubljana, Ljubljana, Slovenia
}

Radiol Oncol 2016; 50(3): 269-273.

Received 5 November 2015

Accepted 7 March 2016

Correspondence to: Maja Mušič Marolt, M.D., Ph.D., Institute of Oncology Ljubljana, Zaloška 2, 1000 Ljubljana, Slovenia. Phone: +386 15879 696; Fax: +386 15879 400; E-mail: mmusic@onko-i.si

Disclosure: No potential conflicts of interest were disclosed.

Background. Preoperative ultrasound (US) evaluation of central and lateral neck compartments is recommended for all patients undergoing a thyroidectomy for malignant or suspicious for malignancy cytologic or molecular findings. Our aim was to find out how frequent was recurrence in regional lymph nodes in patients with follicular or Hürthle cell neoplasm and usefulness of preoperative neck US investigation in patients with neoplasm.

Patients and methods. Altogether 737 patients were surgically treated because of follicular or Hürthle cell neoplasms from 1995 to 2014 at our cancer comprehensive center, among them 207 patients (163 females, 44 males; mean age 52 years) had thyroid carcinoma.

Results. Carcinoma was diagnosed in follicular and Hürthle cell neoplasm in 143/428 and 64/309 of cases, respectively. A recurrence in regional lymph nodes occurred in 12/207 patients (6\%) during a median follow-up of 55 months. Among patients with carcinoma a recurrence in regional lymph nodes was diagnosed in follicular and Hürthle cell neoplasms in $2 \%$ and $14 \%$, respectively $(p=0.002$ ). Recurrence in regional lymph nodes was diagnosed in 3/428 of all patients with follicular neoplasm and 9/309 of all patients with Hürthle cell neoplasm.

Conclusions. Recurrence in lymph nodes was diagnosed in $0.7 \%$ of patients with a preoperative diagnosis of follicular neoplasm and $3 \%$ of patients with a Hürthle cell neoplasm. A recurrence in regional lymph nodes is rare in patients with carcinoma and preoperative diagnosis of follicular neoplasm. Preoperative neck ultrasound examination in patients with a follicular neoplasm is probably not useful, but in patients with Hurtle cell neoplasm it may be useful.

Key words: thyroid neoplasms; ultrasonography; recurrence; diagnosis; pathology

\section{Introduction}

High-resolution ultrasound (US) examination with a $10-13 \mathrm{MHz}$ linear probe detected thyroid nodules in $68 \%$ of randomly selected individuals and $18 \%$ of nodes were larger than $10 \mathrm{~mm} .{ }^{1}$ Diagnostic fine needle aspiration biopsy (FNAB) and cytology of a thyroid nodule is recommended for nodules $\geq 1 \mathrm{~cm}$ with a high suspicion US pattern. ${ }^{2,3}$ The Bethesda system for reporting thyroid cytopathology is used to report thyroid nodule FNAB cytology. ${ }^{4,5}$ The Bethesda IV category comprises follicular neoplasm or suspicious for a follicular neoplasm and also encompasses the diagnosis of Hürthle cell neoplasm/suspicious for Hürthle cell neoplasm. Confirmation of malignancy in these types of primary thyroid tumors is possible only with histological examination of the tumor. ${ }^{4,5}$ Demonstration of transcapsular and/or vascular invasion confirms malignancy. ${ }^{4,5}$ Risk of malignancy in Bethesda IV tumors was $26 \%$ among 2751 patients. ${ }^{6}$ At our institute the risk of malignancy was $33 \%$ and $25 \%$ in follicular and Hürthle cell neoplasms, respectively. ${ }^{7,8}$

According to the NationalCancer Comprehensive Network guidelines for patients with thyroid cancer a preoperative US examination of central and 
lateral neck compartments is recommended for all patients undergoing thyroidectomy for malignant or suspicious for malignancy cytological findings. ${ }^{5}$ Our aim was to find out the frequency of recurrence in regional lymph nodes in patients with carcinoma who had preoperative diagnosis of follicular or Hürthle cell neoplasm and to estimate usefulness of preoperative US examination of the neck region in patients with follicular or Hürthle cell neoplasm.

\section{Patients and methods}

Altogether 737 patients were surgically treated because of follicular $(\mathrm{N}=428)$ or Hürthle cell $(\mathrm{N}=309)$ neoplasms as shown by cytology from 1995 to 2014 at our cancer comprehensive center. Altogether 207 patients (163 females, 44 males; mean age 52 years, range $12-84$ years) had thyroid carcinoma in a dominant nodule as shown by a definitive histopathology. According to the TNM classification system using the UICC criteria from 2009 pT1, pT2, pT3 and pT4 tumor was diagnosed in 69 patients, 68, 64 and 6 patients, respectively. ${ }^{9}$ Metastases in regional lymph nodes and distant metastases were diagnosed in 2 and 10 patients, respectively. A majority of patients were treated by total or near-total thyroidectomy $(87 \%)$ and radioiodine (RAI) ablation of the thyroid remnant $(91 \%)$ followed by a suppressive therapy with L-thyroxine. None of our patients had central or lateral neck dissection during thyroidectomy.

All the patients with carcinoma were followedup at our institute at least once a year (median follow-up period 55 months, range 6-180 months). The follow-up consisted of a medical history, physical examination and determination of serum thyroglobulin $(\mathrm{Tg})$ concentration and $\mathrm{Tg}$ antibodies. The criteria for disease-free survival were: $\mathrm{Tg}$ levels of less than $1 \mathrm{ng} / \mathrm{mL}$, negative whole-body RAI scans, and exclusion of cervical lymph node metastases detected by US as defined by 2009 American Thyroid Association guidelines. ${ }^{2}$ Neck US was always performed within first 6 months after surgery because of thyroid cancer. Neck US was performed at least once per year in case of positive $\mathrm{Tg}$ antibodies. Imaging (X-ray, US, CT, MRI, bone scintigraphy, PET-CT and/or RAI scintigraphy) was performed whenever $\mathrm{Tg}$ concentration was elevated or clinical symptoms of possible recurrence were present in order to determine the site and extent of the suspected recurrence.

A retrospective chart review of all patients with neoplasms was carried out and data about preop- erative US neck examination and recurrence in regional lymph nodes was collected for this study. Predictive factors for the presence of carcinoma in follicular $(\mathrm{N}=388)$ and Hürthle cell $(\mathrm{N}=279)$ neoplasms in our patients have already been published. ${ }^{78}$ Twelve of them had thyroid lesions incidentally detected by 18 F-FDG PET-CT. ${ }^{10}$

A follicular or Hürthle cell neoplasm was diagnosed by FNAB and cytology. FNABs were performed by an endocrinologist, radiologist, and/ or cytopathologist using a 21-23-gauge needle attached to a 10-mL syringe. All cytological slides were examined by cytopathologists and histological slides by pathologists experienced in thyroid pathomorphology. Routine cytological and final pathology reports from our Institute were used in this study.

Preoperative US examination of central and lateral neck compartments were performed in 27 patients with carcinoma who had a preoperative diagnosis of follicular or Hürthle cell neoplasm. Benign cervical LN were sonographically seen as oval shaped, well defined structures with different amount of hilar fat, hilar type of vascularization and transversal diameter in upper regions limited to $9 \mathrm{~mm}$. US criteria for malignant lymph node were: marked hypoechogenicity, rounded shape, absent hilum and irregular, blurred, angular or invasive margins, and presence of microcalcifications. Doppler criteria for malignant lymph node were: peripheral flow, multiple vascular pedicles, chaotic vascular pattern and high impedance values. Probability of malignancy is higher with increasing number of malignant features.

The study was reviewed and approved by the Institutional Review Board and Medical Ethics Committee and was performed in accordance with the medical ethics standards laid down in an appropriate version of the 1964 Declaration of Helsinki. All our patients were asked during the first admission to our institute or a followup visit to give consent to use their charts and biopsy material for scientific purposes. Since the Institutional Review Board of the Institute of Oncology Ljubljana approved this specific study, our patients were not asked to give written consent on this specific study.

\section{Statistical analysis}

The chi-square test was used to compare the observed and expected frequencies of recurrence in regional and lymph nodes in patients with follicular and Hürthle cell neoplasms. A p-value $<0.05$ 
was considered as statistically significant. SPSS 16.0 for Windows was used for statistical analysis.

\section{Results}

Carcinoma was diagnosed in follicular and Hürthle cell neoplasms in 143/428 (33\%) and 64/309 (21\%) of cases, respectively. A follicular variant of papillary thyroid carcinoma, Hürthle cell carcinoma, follicular carcinoma, classical type of papillary carcinoma and other types of papillary carcinoma were diagnosed in 90, 50, 39, 21 and 7 cases, respectively (Table 1). Mean size of carcinoma was $3.46 \mathrm{~cm}$ (range 0.4-11 cm). Microcarcinoma in a dominant nodule was diagnosed in only $8.2 \%$ of patients.

Twelve patients had focal thyroid lesions incidentally detected by $18 \mathrm{~F}-F D G$ PET-CT. Five of them had carcinoma (2 follicular carcinoma, 2 papillary carcinoma and 1 medullary carcinoma), while seven patients had benign tumor (5 adenoma, 2 multinodular goiter). Median tumor size in malignant and benign tumor was $30 \mathrm{~mm}$ and 15 $\mathrm{mm}$, respectively. Median maximal standardized uptake value in malignant and benign tumor was 11 and 6.4 , respectively.

\section{Recurrence in regional lymph nodes}

Recurrence in lymph nodes was diagnosed in 3/428 $(0.7 \%)$ of patients with a preoperative diagnosis of follicular neoplasm and 9/309 (3\%) of patients with a Hürthle cell neoplasm.

Among patients with carcinoma, a recurrence in lymph nodes was detected in $2 \%$ and $14 \%$ of those who had preoperative diagnosis of follicular and Hürthle cell neoplasms, respectively $(p=0.002)$. Recurrence rate in regional lymph nodes according to subtype of carcinoma, tumor size and pT tumor stage is shown in Table 2.

Neither primary tumor diameter or $\mathrm{pT}$ tumor stage was correlated with a recurrence in regional lymph nodes. Primary tumor diameter was $4 \mathrm{~cm}$ or more in $4 / 12$ patients with a recurrence in regional lymph nodes. A recurrence in regional lymph nodes was diagnosed in only 2/12 patients earlier than three years after a thyroidectomy and radioiodine ablation of the thyroid remnant. These two patients had a Hürthle cell neoplasm and concentration of $\mathrm{Tg}$ remained elevated after initial treatment. One of them had a very aggressive Hürthle cell carcinoma which had a regional recurrence in lymph nodes 6 months after a thyroidectomy and radioiodine ablation and bone metastases 11 months thereafter.
TABLE 1. Distribution of follicular and Hürthle cell neoplasms and carcinoma subtype

\begin{tabular}{lccc}
\hline \multirow{2}{*}{ Carcinoma type } & \multicolumn{2}{c}{ Type of neoplasm } & Total \\
\cline { 2 - 3 } & $\begin{array}{c}\text { Follicular } \\
\text { neoplasm }\end{array}$ & $\begin{array}{c}\text { Hürthle cell } \\
\text { neoplasm }\end{array}$ & \\
\hline Follicular & 31 & 8 & 39 \\
Hürthle cell & 12 & 38 & 50 \\
Papillary - classical variant & 16 & 5 & 21 \\
Papillary - follicular variant & 81 & 9 & 90 \\
Papillary - Other variant* & 3 & 4 & 7 \\
Total & 143 & 64 & 207 \\
\hline
\end{tabular}

* Oncocytic variant in 4 cases, trabecular variant in 2 cases, poorly differentiated thyroid carcinoma in 1 case

TABLE 2. Recurrence rate in regional lymph nodes and subtype of carcinoma, pT, pN, M and tumor size in 207 patients with malignant follicular or Hürthle cell neoplasm

\begin{tabular}{|c|c|c|c|c|}
\hline \multirow{2}{*}{ Carcinoma type } & \multirow{2}{*}{ Total } & \multicolumn{2}{|c|}{$\begin{array}{l}\text { Recurrence in } \\
\text { regional lymph nodes }\end{array}$} & \multirow{2}{*}{ p-value } \\
\hline & & No & Yes & \\
\hline $\begin{array}{l}\text { Follicular } \\
\text { Hürthle cell } \\
\text { Papillary - classical variant } \\
\text { Papillary - follicular variant } \\
\text { Papillary - other variant }\end{array}$ & $\begin{array}{c}39 \\
50 \\
21 \\
90 \\
7\end{array}$ & $\begin{array}{l}37 \\
42 \\
20 \\
89 \\
7\end{array}$ & $\begin{array}{l}2 \\
8 \\
1 \\
1 \\
0\end{array}$ & 0.008 \\
\hline $\begin{array}{l}\text { pT1 } \\
\text { pT2 } \\
\text { pT3 } \\
\text { pT4 }\end{array}$ & $\begin{array}{l}69 \\
68 \\
64 \\
6\end{array}$ & $\begin{array}{c}69 \\
62 \\
59 \\
5\end{array}$ & $\begin{array}{l}0 \\
6 \\
5 \\
1\end{array}$ & 0.067 \\
\hline $\begin{array}{l}\mathrm{pNO} \\
\mathrm{pNI}\end{array}$ & $\begin{array}{c}205 \\
2\end{array}$ & $\begin{array}{c}194 \\
1\end{array}$ & $\begin{array}{c}11 \\
1\end{array}$ & 0.113 \\
\hline $\begin{array}{l}\text { MO } \\
\text { M1 }\end{array}$ & $\begin{array}{c}197 \\
10\end{array}$ & $\begin{array}{l}188 \\
7\end{array}$ & $\begin{array}{l}9 \\
3\end{array}$ & 0.014 \\
\hline $\begin{array}{lc}\text { Tumor diameter } & 0.4-4 \mathrm{~cm} \\
\text { Tumor diameter } & 4.01-11 \mathrm{~cm}\end{array}$ & $\begin{array}{c}145 \\
62\end{array}$ & $\begin{array}{c}137 \\
58\end{array}$ & $\begin{array}{l}8 \\
4\end{array}$ & 0.75 \\
\hline Total & 207 & 195 & 12 & - \\
\hline
\end{tabular}

TABLE 3. Preoperative neck US and recurrence in regional lymph nodes in patients with follicular and Hürthle cell neoplasms (Fisher's exact test $p=0.296$ )

\begin{tabular}{lccc}
\hline \multirow{2}{*}{ Type of neoplasm } & \multicolumn{2}{c}{ Recurrence in regional lymph nodes } & \multirow{2}{*}{ Total } \\
\cline { 2 - 3 } & No & Yes & \\
\hline Follicular & 19 & 0 & 19 \\
Hüthle cell & 7 & 1 & 8 \\
Total & 26 & 1 & 27 \\
\hline
\end{tabular}

From our cohort of patients, these two cases are the only ones in whom a preoperative US examination would have shown the presence of metastases in regional lymph nodes and therefore the treatment would have been changed.

After initial treatment altogether $8 / 12$ patients had suppressed thyroglobulin $(\mathrm{Tg})<1 \mathrm{ng} / \mathrm{mL}$, TSHstimulated $\mathrm{Tg}<10 \mathrm{ng} / \mathrm{ml}$, or stable or decreasing levels of Tg antibodies and an absence of structural 
disease. Two of the remaining four patients had distant metastases soon after a regional relapse.

\section{Preoperative neck US examination}

Preoperative US examination of the neck region was performed in 27 patients with thyroid carcinoma (Table 3): in 12 , 6, 5, 1 and 3 cases with a follicular variant of papillary carcinoma, Hürthle cell carcinoma, follicular carcinoma, classical type of papillary carcinoma and other types of papillary carcinoma, respectively. In patients who underwent preoperative US examination of the neck region no pathological lymph nodes were detected. However, a recurrence in regional lymph nodes was diagnosed in one of 26 patients six years after thyroid surgery. This patient had a follicular variant of papillary carcinoma.

In only 2 of 12 patients with a recurrence in regional lymph nodes it was diagnosed earlier than three years after thyroidectomy. After modified radical neck dissection in one of them, there is no evidence of disease. However, the other one had a very aggressive Hürthle cell carcinoma in whom a preoperative US would probably have shown the presence of metastases in regional lymph nodes which could have changed the treatment and possibly his outcome. However, it is very doubtful if, in the remaining 10 patients with a recurrence, metastases in regional lymph could have been detected with a preoperative US examination. Among patients with a recurrence in regional lymph nodes after a thyroidectomy and radioiodine ablation of the thyroid remnant, altogether 8/12 patients had suppressed thyroglobulin $(\mathrm{Tg})<1 \mathrm{ng} / \mathrm{mL}$, TSH-stimulated $\mathrm{Tg}<$ $10 \mathrm{ng} / \mathrm{ml}$, or stable or decreasing Tg antibody levels or the presence of structural disease. Therefore we believe that there are only two patients from our cohort of patients in whom a preoperative US examination would have shown the presence of metastatic lymph nodes which would probably have changed the treatment and his outcome.

\section{Discussion}

Preoperative US examination of central and lateral neck compartments is recommended for all patients undergoing a thyroidectomy because of malignant or suspicious for malignancy cytology. Namely, cervical lymph node metastases were found in as many as $50 \%$ of patients with carci- noma. ${ }^{11-13}$ Because preoperative US examination of the neck region detects metastases in cervical lymph nodes in $23-33 \%$ of patients the surgical approach is changed. ${ }^{14,15}$ In the literature, there is very limited data on the frequency of involvement of cervical lymph nodes in patients with follicular or Hürthle cell neoplasms. Paunovic et al. reported the presence of regional lymph node metastases in $2 \%$ of patients with a Hürthle cell neoplasm. ${ }^{16}$

Our study was observational and not randomized, thus it is not possible to draw conclusions about the impact of preoperative US examination on the surgical approach or patients' outcomes. However, it has shown in a large dataset of patients that recurrence in regional lymph nodes was detected in only $0.7 \%$ of patients with preoperative diagnosis of a follicular neoplasm and 3\% of patients with a Hürthle cell neoplasm. Based on these findings our opinion is that preoperative US examination of the neck region is not useful in patients with a follicular neoplasm. On the other hand, in patients with a Hürthle cell neoplasm preoperative US examination of the neck region may be useful.

A recurrence in regional lymph nodes occurred in $6 \%$ of our patients with a carcinoma during a median follow-up of 55 months. The outcomes of our patients are in accordance with reports from the literature. During a median follow-up period of 7 years after a total thyroidectomy and radioiodine ablation of the thyroid remnant a recurrence rate was reported to occur in low risk patients in 3\%, in intermediate risk patients in $21 \%$, and in high risk patients in $68 \% .{ }^{17}$ In papillary thyroid carcinoma (PTC), a recurrence was diagnosed in papillary microcarcinoma in $1-3 \%$ of patients. ${ }^{18,19}$ The ten-year regional recurrence rate of $\mathrm{T} 1, \mathrm{~T} 2$, and $\mathrm{T} 3$ patients with PTC was $1.9,4.6$, and $8.1 \%$, respectively. ${ }^{20}$ In our patients with PTC a recurrence in regional lymph nodes was diagnosed in only 2 of $118(1.7 \%)$ patients. But it should be stressed that the median follow-up in our study was only 55 months. It is well known that in thyroid carcinoma recurrences occur years after initial treatment. ${ }^{20-22}$

Our study confirmed the well-known fact that the recurrence rate in regional lymph nodes is common in Hürthle cell carcinoma. ${ }^{23-26}$ It was diagnosed in as much as $16 \%$ of patients with Hürthle cell carcinoma. The recurrence rate in our patients is comparable to reports in the literature. Khafif et al., Stojadinovic et al. and Mills et al. reported that locoregional recurrence occurred in 10.5\%, 16\% and $34 \%$ of cases, respectively. ${ }^{23-25}$ 


\section{Conclusions}

Preoperative neck ultrasound examination in patients with a follicular neoplasm is probably not useful, but in patients with Hurtle cell neoplasm it may be useful. Recurrence in lymph nodes was diagnosed in $0.7 \%$ of patients with a preoperative diagnosis of follicular neoplasm and $3 \%$ of patients with a Hürthle cell neoplasm. A recurrence in regional lymph nodes is rare in patients with carcinoma and preoperative diagnosis of follicular neoplasm.

\section{Acknowledgement}

This paper is a part of Research Study No. P3-0289 supported by the Ministry of Higher Education, Science, and Technology of the Republic of Slovenia.

\section{References}

1. Guth S, Theune U, Aberle J, Galach A, Bamberger CM. Very high prevalence of thyroid nodules detected by high frequency $(13 \mathrm{MHz})$ ultrasound examination. Eur J Clin Invest 2009; 39: 699-706.

2. American Thyroid Association (ATA) Guidelines Taskforce on Thyroid Nodules and Differentiated Thyroid Cancer, Cooper DS, Doherty GM, Haugen BR, et al. Revised American Thyroid Association management guidelines for patients with thyroid nodules and differentiated thyroid cancer. Thyroid 2009; 19: 1167-214.

3. Ito $\mathrm{Y}$, Amino $\mathrm{N}$, Yokozawa $\mathrm{T}$, Ota $\mathrm{H}$, Ohshita $\mathrm{M}$, Murata $\mathrm{N}$, et al. Ultrasonographic evaluation of thyroid nodules in 900 patients: comparison among ultrasonographic, cytological, and histological findings. Thyroid 2007; 17: 1269-76.

4. Baloch ZW, LiVolsi VA, Asa SL, Rosai J, Merino MJ, Randolph G, et al. Diagnostic terminology and morphologic criteria for cytologic diagnosis of thyroid lesions: a synopsis of the National Cancer Institute Thyroid FineNeedle Aspiration State of the Science Conference. Diagn Cytopathol 2008; 36: 425-37.

5. National Comprehensive Cancer Network (2015) NCCN Clinical practice guidelines in oncology (NCCN Guidelines) Thyroid carcinoma. Version 2.2015. National Comprehensive Cancer Network, Washington. Available at http://www.nccn.org/professionals/physician_gls/f_guidelines. asp\#thyroid. Accessed on 21 August 2015

6. Bongiovanni M, Spitale A, Faquin WC, Mazzucchelli L, Baloch ZW. The Bethesda System for Reporting Thyroid Cytopathology: a meta-analysis. Acta Cytol 2012; 56: 333-9.

7. Petric R, Perhavec A, Gazic B, Besic N. Preoperative serum thyroglobulin concentration is an independent predictive factor of malignancy in follicular neoplasms of the thyroid gland. J Surg Oncol 2012; 105: 351-6.

8. Strazisar B, Petric R, Sesek M, Zgajnar J, Hocevar M, Besic N. Predictive factors of carcinoma in 279 patients with Hürthle cell neoplasm of the thyroid gland. J Surg Oncol 2010; 101: 582-6.

9. Sobin LH, Gospodarowitz MK, Witekind C. Thyroid gland (ICD-O C73). In: Sobin LH, Gospodarowitz MK, Witekind C, editors. TNM classification of malignant tumours. 7th edition. New York: Wiley Blackwell; 2009. p. 58-62.

10. Jamsek J, Zagar I, Gaberscek S, Grmek M. Thyroid lesions incidentally detected by (18)F-FDG PET-CT - a two centre retrospective study. Radiol Oncol 2015; 49: 121-7.
11. Nam-Goong IS, Kim HY, Gong G, Lee HK, Hong SJ, Kim WB, Shong YK. Ultrasonography-guided fine-needle aspiration of thyroid incidentaloma: correlation with pathological findings. Clin Endocrinol (Oxf) 2004; 60: 21-8.

12. Scheumann GF, Gimm O, Wegener G, Hundeshagen H, Dralle H. Prognostic significance and surgical management of locoregional lymph node metastases in papillary thyroid cancer. World J Surg 1994; 18: 559-67.

13. Ito Y, Miyauchi A. Lateral lymph node dissection guided by preoperative and intraoperative findings in differentiated thyroid carcinoma. World J Surg 2008; 32: 729-39.

14. Stulak JM, Grant CS, Farley DR, Thompson GB, van Heerden JA, Hay ID, et al. Value of preoperative ultrasonography in the surgical management of initial and reoperative papillary thyroid cancer. Arch Surg 2006; 141: 489-94.

15. O'Connell K, Yen TW, Quiroz F, Evans DB, Wang TS. The utility of routine preoperative cervical ultrasonography in patients undergoing thyroidectomy for differentiated thyroid cancer. Surgery 2013; 154: 697-701.

16. Paunovic I, Krgovic K, Tatic S, Diklic A, Zivaljevic V, Kalezic N, Havelka M. Surgery for thyroid Hürthle cell tumours - a single institution experience. Eur J Surg Oncol 2006; 32: 458-61.

17. Tuttle RM, Tala H, Shah J, Leboeuf R, Ghossein R, Gonen M, et al. Estimating risk of recurrence in differentiated thyroid cancer after total thyroidectomy and radioactive iodine remnant ablation: using response to therapy variables to modify the initial risk estimates predicted by the new American Thyroid Association staging system. Thyroid 2010; 20: 1341-9.

18. Roti E, degli Uberti EC, Bondanelli M, Braverman LE. Thyroid papillary microcarcinoma: a descriptive and meta-analysis study. Eur J Endocrinol; 159: 659-73.

19. Besic N, Pilko G, Petric R, Hocevar M, Zgajnar J. (2008) Papillary thyroid microcarcinoma: prognostic factors and treatment. J Surg Oncol 2008; 97: 221-5.

20. Ito $Y$, Kudo T, Kihara M, Takamura Y, Kobayashi K, Miya A, Miyauchi A Prognosis of low-risk papillary thyroid carcinoma patients: its relationship with the size of primary tumors. Endocr J 2012; 59: 119-25.

21. Mazzaferri EL. An overview of the management of papillary and follicular thyroid carcinoma. Thyroid 1999; 9: 421-7.

22. Hay ID, Thompson GB, Grant CS, Bergstralh EJ, Dvorak CE, Gorman CA, et al. Papillary thyroid carcinoma managed at the Mayo Clinic during six decades (1940-1999): temporal trends in initial therapy and long-term outcome in 2444 consecutively treated patients. World J Surg 2002; 26: 879-85.

23. Khafif A, Khafif RA, Attie JN. Hurthle cell carcinoma: a malignancy of lowgrade potential. Head Neck 1999; 21: 506-11.

24. Stojadinovic A, Hoos A, Ghossein RA, Urist MJ, Leung DH, Spiro RH, et al. Hürthle cell carcinoma: a 60-year experience. Ann Surg Oncol 2002; 9: 197-203.

25. Mills SC, Haq M, Smellie WJ, Harmer C. Hurthle cell carcinoma of the thyroid: retrospective review of 62 patients treated at the Royal Marsden Hospital between 1946 and 2003. Eur J Surg Oncol 2009; 35: 230-4.

26. Petric R, Gazic B, Besic N. Prognostic factors for disease-specific survival in 108 patients with Hürthle cell thyroid carcinoma: a single-institution experience. BMC Cancer 2014; 14: 777. 